\title{
Introduction
}

In 2019 the municipal government of Madrid sponsored the exhibition Madrid, ciudad educadora 1898/1938. Memoria de la escuela pública (Madrid, educational city 1898/1938. Memory of public school) which focused on the pedagogical renewal that took place in the public schools of the city in the years before the start of the Franco dictatorship in 1939. ${ }^{1}$ The exhibition showed examples of progressive educational practices in Madrid's public schools at the beginning of the twentieth century that were practically unknown. For the oldest generations, including those who had attended public schools in the 1930s themselves, the exhibition was bound to awaken memories of times long past. For older generations - those educated under Francoism - the exhibition would highlight the contrast between the practices depicted here and the authoritarian type of education that they received in these same schools. For younger generations - those enrolled in primary schools in democratic Spain the exhibition was a true revelation in its portrayal of the parallelism between modern educational experiences and the roots of progressive educational practices that date back to the early decades of the twentieth century. For the very youngest generations children and teenagers in 2019 - we can imagine the exhibition serving to heighten their awareness about the horrific consequences of war for the life of fellow pupils.

From an academic and historical point of view, the exhibition also told a relevant story. It intended to show that at a time when a second industrial revolution was taking place in the Western world, and when new progressive, child-centered ideas about education were being introduced in school systems, the Spanish capital was just as engaged as other more well-known examples in the educational world. In Spain, which was struggling with serious social problems at the end of the nineteenth century, partly related to the loss of its last colonies - Cuba and the Philippines - to

\footnotetext{
1 "Madrid, ciudad educadora 1898/1938 - Memoria de la escuela pública," https://www.esmadrid.com/ agenda/madrid-ciudad-educadora-18981938-memoria-escuela-publica-museo-historia\# (accessed August 28, 2020).

This chapter was written as part of the project entitled School Culture and Practices in the Twentieth Century, EDU2017-82485-P, funded by the Spanish Ministry of Science, Innovation and Universities (MCIU), the National Research Agency (AEI), and European Regional Development Funds (ERDF, EU).
} 
the USA, education was being promoted as a motor for social change. ${ }^{2}$ The power of education to change society through the development of new models for schooling was an important underlying message of the exhibition - one in line with the main findings of academic historical research. ${ }^{3}$

The specific historical foundation for this exhibition was laid out in a Ph.D. thesis published in 1999 by the first author of this article. ${ }^{4}$ The concept of the exhibition was also based on academic articles and books written in recent years about progressive education experiences and schoolteachers in Spain and its capital. ${ }^{5}$ It goes without saying that all of the research for the exhibit was based on a rigorous exploration of all available primary historical sources found in public and private archives. An important element was the collation of an image archive by the first author covering the early decades of the twentieth century. However, despite this pursuit of scientific "objectivity", it should be added immediately that the exhibition, and the final selection of the images on display, had a clear political bent from the beginning.

After several legislatures of conservative political majorities, in 2015 the Madrid City Council found itself in the hands of a left-wing municipal government. This change was reflected, among other things, in a preference for urban projects in which historical references to General Franco's political regime were replaced by references to persons, institutions or events associated with the history of the Second Republic, the democratic government that preceded Franco's dictatorship. Part of the "memory policy" of the city council was to support exhibitions and other public events in which residents of Madrid, both young and old, could learn about the merits of progressive sociocultural policies that had been abruptly cut off after 1939. Another example of this policy was the replacement of street names referring to Franco-era (military) icons for new names recalling (educational) heroes from the era of the Second Republic. The proposals for street names offered by the body that the city council put in charge of this task - The Commission for Historical Memory (2016-2018) - were disputed fiercely by some of the more nostalgic Francoist sectors. The Francisco Franco Foundation itself appealed before the court and in 2017, managed to halt changes to the names of 52 streets that commemorated events or figures from the Franco era. This battle for the symbolic stage represented by Madrid's streets brought to light the enormous ideological and symbolic weight that the term "memory" carries in Spain.

2 María del Mar del Pozo Andrés, Currículum e identidad nacional. Regeneracionismos, nacionalismos y escuela pública (1890-1939) (Madrid: Biblioteca Nueva, 2000), 67-81.

3 Hugh Lauder, Phillip Brown, Jo-Anne Dillabough, and A.H. Halsey, Education, Globalization and Social Change (New York: Oxford University Press, 2006).

4 María del Mar del Pozo Andrés, Urbanismo y Educación. Política educativa y expansión escolar en Madrid (1900-1931) (Madrid: Universidad de Alcalá, 1999).

5 See a summary of the recent findings in María del Mar del Pozo Andrés, "Madrid, a Showcase for National Pedagogical Renovation (1898-1936)," in Madrid, ciudad educadora 1898/1938. Memoria de la escuela pública, ed. María del Mar del Pozo Andrés (Madrid: Ayuntamiento de Madrid, 2019), 297-325. 
In 2017, Madrid City Council, through its Office of Human Rights and Memory, launched the "Madrid, City of Memory" campaign, which was meant to develop a "public policy of memory," ${ }^{6}$ based on the Law of Historical Memory passed by the socialist government in 2007. This law sought to encourage democratic values by facilitating a clearer knowledge of historical events that took place during the Civil War and the Francoist dictatorship. In Spain, the term "historical memory" is understood to refer to the years between 1936 and 1975. However, given that the war was the result of a military uprising against a political regime established democratically in 1931, the years prior to the outbreak of war are crucial for understanding the construction of democratic memory in Spain. The City Council's objectives in underwriting an exhibit on public primary schools from the Republican era were: to recover school memory from the Republican period; to present this memory to Madrilenians as a crowning moment for progressive educational policies; and to recount its destruction and demise in the first years of Franco's dictatorship. These goals did not necessarily coincide with the scholarly objectives of academic historians.

While policy makers are interested in activating knowledge about progressive educational practices to support public educational institutions and interest groups, academic historians tend to prefer reflexive knowledge about the development of educational practices in a changing social context. And where policy makers would be quite satisfied with an exhibition in which educational progress in the first decades of the twentieth century would be causally linked with the political changes that happened because of the Second Republic (1931-1936), academic historians would be more inclined to highlight the continuities in educational change and the relationship with socioeconomic and cultural changes taking place over a longer period (1898-1938). In short, the groups involved in organizing an exhibition do not necessarily agree with each other regarding the goals. Nor is this necessarily a problem. It merely means that, in the end, an exhibition will be the result of negotiations between various stakeholders. In other words, the historical knowledge to be displayed represents the outcome of an interplay between actors with different degrees of power.

The presentation of reflexive knowledge to a wide, non-academic audience by professional historians is known nowadays as "public history". 7 For several decades now, it has constituted a vibrant and challenging field where professional historians interact with multiple audiences, ranging from experts to laymen, but also including policy makers and policy influencers, all united by their interest in history, memory, heritage, and material culture. With the growing and global popular interest in historical issues

6 Interview with Txema Urquijo, head of Historic Memory in the City Council of Madrid (20172019), elDiario.es, February 21, 2020, https://www.eldiario.es/madrid/exresponsable-memoria-his torica-carmena-comisionado_1_1121225.html (accessed September 2, 2020).

7 See also Michael Burawoy, “For Public Sociology,” American Sociological Review 70, no. 1 (2005): 4-28. 
related to gender, religion, race, nation, and identity, public history is at this time arguably the strongest branch of history as an academic discipline. This recent success is attested to the slew of new textbooks, handbooks, reference works, and journals that have been published. ${ }^{8}$

Although many historians are reluctant to admit that stories about the past can provide us with lessons for the future, the general public is still interested in lessons that history may teach us. Let us take the recent COVID-19 pandemic as an example: the first reports in the news media - when the medical sciences were hard put to provide any objective information about the coronavirus - invariably referred to historical examples such as the medieval plague and the Spanish flu of $1918 .{ }^{9}$ It seemed that if the hard sciences could not yet provide answers, a soft science (or art) like history ${ }^{10}$ suddenly mattered a great deal to many audiences.

The global anti-racist protests following George Floyd's death and intensified by the Black Lives Matter movement provide another example: historical facts about, among others, Edward Colston, the Bristol merchant and philanthropist, ${ }^{11}$ and Winston Churchill, the British prime minister and World War II hero, ${ }^{12}$ are used as evidence to condemn both figures as racists and to take down or deface their statues. Without going into the details of these cases, certain things are clear: historical facts play an important role in public debates; and historical facts carry a subjective, political charge. If, according to historians, history cannot teach us lessons, history certainly does matter to the public.

The hermeneutical approach to history as a discipline applies not only to the texts that were ultimately presented in the exhibition Madrid, ciudad educadora 1898/1938. Memoria de la escuela pública, but also to the visual material that was on display. It should be noted that in order to especially increase the appeal of the

8 See especially: Thomas Cauvin, Public History: A Textbook of Practice (London: Routledge, 2016); Cherstin M. Lyon, Elizabeth M. Nix, and Rebecca K. Shrum, eds., Introduction to Public History: Interpreting the Past, Engaging Audiences (Lanham, Boulder, New York, London: Rowman \& Littlefield, 2017); James B. Gardner and Paula Hamilton, eds., The Oxford Handbook of Public History (Oxford: Oxford University Press, 2017); David Dean, ed., A Companion to Public History (Hoboken, NJ: Wiley, 2018); and Faye Sayer, Public History: A Practical Guide (London: Bloomsbury, 2019).

9 Stephen Dowling, "Coronavirus: What Can We Learn from the Spanish Flu," March 3, 2020, https://www.bbc.com/future/article/20200302-coronavirus-what-can-we-learn-from-the-spanishflu (accessed July 25, 2020).

10 See for the discussion about history as art or science: Herman Tennessen, "History Is Science," The Monist 53, no. 1 (1969): 116-133, DOI: https://doi.org/10.5840/monist19695312 (accessed August 2, 2020).

11 Kenneth Morgan, Edward Colston and Bristol. Local History Pamphlets Series, no. 96 (Bristol: The Bristol Branch of the Historical Association, 1999), http://www.bris.ac.uk/Depts/History/bristolre cordsociety/publications/bha096.pdf (accessed August 1, 2020).

12 Richard Toye, “Yes, Churchill Was a Racist: It’s Time to Break Free of his ‘Great White Men' View of History,” July 10, 2020, https://edition.cnn.com/2020/06/10/opinions/churchill-racist-greatwhite-men-view-toye-opinion/index.html (accessed August 1, 2020). 
exhibition and its impact on visitors, much original photographic material dealing with historical schools, teachers, and pupils was collected for the event (some 500 documents). Inevitably, issues arose regarding which images should be displayed and which left out. In selecting images and texts, academic historians obviously had to consider general matters of privacy and copyright, while also having to take into account the specific views of the city council, as the main exhibition sponsor. At the very least, this implied a tension between the role of educational historians as professional representatives of a scientific discipline, and their role as public historians working for a local government organization. In turn, many more tensions exist due to the fact that, along with political and scientific representatives, numerous other stakeholders are involved in a public exhibition. This brings us to the questions we would like to address in this article:

What challenges do academic historians have to face when organizing an educational exhibition for a non-academic audience? Which stakeholders play a role in this process? And how are decisions about content and form made, particularly in relation to the choice of images?

\section{Stakeholders and Exhibitions}

Exhibitions, defined as events at which products and services are displayed, are part of what is called the "meetings industry."13 Along with exhibitions - and here we follow the terminology developed by the International Association of Professional Congress Organizers (IAPCO) - there are also meetings, a general term indicating the coming together of a number of people in one place to confer or carry out a particular activity; incentives, meeting events as part of a program offered to its participants in reward for a previous performance; and conferences, participatory meetings for discussion, fact-finding, problem solving, and consultation. ${ }^{14}$ In terms of the amount of money and people involved, the meetings industry is an important part of global travel and tourism. The meetings industry, like the educational sector, has the power to bring people and knowledge together. And in the same way that education implies much more than a teacher instructing a group of students, an exhibition is much more than a public display of texts, images, and objects. An exhibition is a multimodal presentation of a central idea or concept, accompanied by other activities,

13 International Congress and Convention Association, "The definition of MICE," https://www.icca world.org/aeps/aeitem.cfm?aeid=29 (accessed August 2, 2020).

14 Commission of the European Communities and International Association of Professional Congress Organizers, Meeting Industry Terminology (Luxembourg: Office for Official Publications of the European Communities, 1992), https://termcoord.eu/wp-content/uploads/2016/07/meeting-indus try-terminology1.pdf (accessed August 2, 2020). 
within a wider context of cultural learning, and limited by economic and political boundaries.

This was certainly true for the exhibition Madrid, ciudad educadora 1898/1938. Memoria de la escuela pública. Not only did it encompass an exposition of engravings, photographs, videos, maps, wall charts, books, letters, and other material objects (with accompanying text) in four large rooms of a municipal museum in the center of Madrid, the Museo de Historia de Madrid; it was also accompanied by twelve meetings with lectures, poems, and music in the iconic Cibeles Palace in Madrid. In addition to these events, a 466-page catalogue was published with articles from scholars from Spain, Italy, and the United Kingdom, printed in both Spanish and English and illustrated with more than 200 color photographs. ${ }^{15}$ Guided tours, which included a free 24-page children's workbook, were organized for students from Madrid's schools. ${ }^{16}$

Organizing an exhibition like this means considering various stakeholders. The concept of stakeholder dates to the 1970s, when the term made its appearance in organizational management theories next to the well-known financial term "shareholder". It gradually became clear that managing a company involved more than the two parties, represented by consumers buying products (on the demand side) and shareholders getting a return on their investments (on the supply side). Mapping the sociocultural environment of a company began to be necessary for developing an effective strategy for managing a business and being prepared for ethical challenges raised by many parties. Every exhibition has its share of vested stakeholders. The journal Exhibition World mentions at least six or seven:

The event owner, the event organizer (which can be the same organization as the owner), the industry sector (which the exhibition represents), the host destination, the exhibitors, the visitors, and the service providers. All these stakeholder categories have an interest in the success of the event. The objectives of these stakeholders range from exhibitor and visitor satisfaction, advancement of trade and commerce, development of research and knowledge transfer, promotion of the destination and/or venue, sales and product awareness, education and challenge solutions, and of course revenues and profits. ${ }^{17}$

If we apply this classification to the organization of the exhibition Madrid, ciudad educadora 1898/1938. Memoria de la escuela pública, we end up with Tab. 5.1.

The first thing requiring comment is that organization responsibilities were shared by an academic historian, who has written extensively on the history of the public

15 Pozo Andrés, Madrid, ciudad educadora 1898/1938.

16 Fundación Ángel Llorca, Madrid, ciudad educadora 1898/1938. Una mirada para la infancia (Madrid: Ayuntamiento de Madrid, 2019).

17 Jerad Bachar, “Measuring the Impact of Exhibitions," Exhibition World 4 no. 4 (2015), https:// www.exhibitionworld.co.uk/2015/07/02/measuring-the-impact-of-exhibitions (accessed August 3, 2020). 
Tab. 5.1: Stakeholders at the exhibition Madrid, ciudad educadora 1898/1938. Memoria de la escuela pública.

\begin{tabular}{ll}
\hline The event owner & $\begin{array}{l}\text { The municipal government of Madrid, especially the Office for Human } \\
\text { Rights and Memory }\end{array}$ \\
\hline The event organizer & $\begin{array}{l}\text { Historian of education (University of Alcalá) Educational interest group } \\
\text { (Ángel Llorca Foundation) }\end{array}$ \\
\hline The sector & The education sector \\
\hline The host destination & The municipal Museum of History of Madrid \\
\hline The exhibitors & Public schools; museums; archives; libraries; private collectors \\
\hline The visitors & Citizens of Madrid and other parts of Spain; foreign tourists \\
\hline The service providers & $\begin{array}{l}\text { Exhibition designers; video mappers; cartographers; academic advisors; } \\
\text { photographers; restorers; transporters; scaffolders; security personnel; } \\
\text { exhibition guides }\end{array}$ \\
\hline
\end{tabular}

schools in Madrid, and the representatives of an educational interest group that has been working to preserve the memory of Ángel Llorca, a public schoolteacher and director of the experimental Cervantes School in 1920s and 30s Madrid. This educational interest group had the legal structure of a foundation. The Ángel Llorca Foundation was established as part of Acción Educativa, a movement for pedagogical renewal focused on the defense of public schools. ${ }^{18}$ By preserving the legacy and memory of past public schools, this foundation seeks to bolster today's public schools. ${ }^{19}$ The historian was connected to the foundation as a member of its board of trustees. Ultimately, the foundation and its representatives acted in the capacity of administrative organizers of the exhibition, while the historian assumed the role of scientific organizer and developed the concept of the exhibition as a whole.

In addition to these two actors, several other parties were involved in the organization of the exhibition. Chief among these were the municipal government of Madrid, in particular the Office for Human Rights and Memory (the event owner); the municipal museum for the History of Madrid (the host destination); and Smart \& Green Design and Wot Studio (the exhibition designers).

In the case of this exhibition, exhibitors played a passive role. All of the head teachers of the 41 public schools in the city of Madrid considered "historic schools"20 were contacted and visited by the event organizers. The purpose of this was to select

18 “Acción Educativa,” http://accioneducativa-mrp.org/ (accessed August 5, 2020).

19 “Fundación Ángel Llorca,” http://www.fundacionangelllorca.org/fundacion/ (accessed August 5, 2020).

20 María del Mar del Pozo Andrés, “Las escuelas públicas históricas de Madrid,” in Madrid, ciudad educadora 1898/1938, 379-384. 
and secure approval for the use of educational objects and material from the first third of the twentieth century that made up part of the historical heritage at these institutions. A similar procedure was followed with representatives of museums (especially the Laboratory Museum of History of Education "Manuel Bartolomé Cossio" in Madrid), archives (particularly the Archivo General de la Administración in Alcalá de Henares), libraries (especially the National Library), and private collectors (in particular, the collection of Antonio Molero).

\section{Tensions between Historians and Stakeholders}

After our brief description of the stakeholders of an exhibition, we will now focus on some examples of the challenges an historian can face when dealing with these various groups.

Tensions with the event owner: In this specific instance, the event owner was a political group interested in revitalizing the memory of the Second Spanish Republic, especially in relation to its progressive educational policies. This intention was manifest in some of the initial drafts for the exhibit program and the prologue to the catalog, where municipal advisers wrongly affirmed that levels of illiteracy had remained unchanged in Madrid between 1875 and 1931, but rightly claimed that these levels were reduced dramatically under the Second Republic. Ultimately, however, the exhibition dealt with the period 1898-1938; its starting point was the loss of the last Spanish colonies in Cuba and Philippines, and the ensuing plans for a regeneration of the country, especially by means of education. The period covered ends with the closing of the schools in the capital and the evacuation of pupils to children's camps near the Mediterranean Sea. In other words, the period of the exhibition was chosen in relation to important educational dates. These dates were not determined by political markers such as the beginning of the Second Republic or the end of the Civil War. By choosing this specific time frame, and not the period 1931-1939, the exhibition dispensed with its explicit link to the Second Republic. While doubts remained as to whether the period prior to 1931 could be considered part of the historical memory contemplated by the law of 2007, the municipality as event owner respected the choices made by the academic historian.

Tensions with the service providers: A possible conflict with the creative designers, as the most important service provider, arose with the choice of the colors of the exhibition's shelves. The designers, bearing in mind what they anticipated to be the wish of the municipality and the Ângel Llorca Foundation, chose three basic colors: red, yellow, and purple. These just happen to be the colors of the Second Republic flag. The academic historian rejected this idea; the exhibition was meant to show continuities and discontinuities in a period stretching beyond the years of the Republic. Ultimately, the metal Meccano-like racks were made in the basic colors of red, yellow, blue, and 
green - evoking the colors of the children's board game Parchisi. Instead of a veiled political message, this more immediate, playful reference served to ensure that the key concept of the exhibition would be childhood itself. Children did in fact constitute the central element of most of the images and objects displayed.

Tensions with the exhibitors: The main exhibitors in Madrid, ciudad educadora 1898/1938. Memoria de la escuela pública were the historical schools of Madrid. The representatives of these schools had to be visited and convinced of the importance of participating in the project and, in particular, of making educational material available. While this would not seem to be a difficult task, in practice it posed several problems. Not all the school principals were keen about an exhibition inspired by a municipal government whose specific political color did not necessarily match that of the school's principal, staff, parents, or the school community in general. Other schools simply did not have any interesting historical objects to boast of or were unable to provide such material for lack of time. Finally, 31 of Madrid's 41 historical schools agreed to collaborate.

Tensions with the host destination: The exhibition took place in the municipal $\mathrm{Mu}-$ seum of History of Madrid. This implied a direct political relationship between the event owner and the host destination. In principle, this connection was not problematic for the event organizers. The fact that the representatives of the museum also derived their legitimacy from the possession of historical knowledge was a potential source of tension. Ultimately, museum management was also in charge of the logistics operations, as well as the use of space and the possible extension of the exhibition dates.

Tensions with the visitors: The task of historians who work in or with museums is to be "advocates for both history and visitors, negotiating the gap between our understanding of the past as historians and the public's". ${ }^{21}$ There is much to be said about the relationship between academic historians as event organizers and the public attending an exhibition. In this case, we will limit ourselves to the issue of the "sharing" of photographs. On the initiative of the academic historian, one of the decisions taken at the start of the exhibition was to prohibit photographs of the display. The obvious reason was that copyright had to be paid for the reproduction of photos. Nevertheless, there was an additional reason: searching through archives and finding photographs that had never before been shown to the public was the work of the historians involved in organizing the exhibition; allowing photographs to be taken during the exhibition was sure to result in the publication of photo collections on blog sites and other Internet sources, with no mention of the origin of the photo or of the historians who had discovered them in archives. Eventually, despite the ban, some photos of the exhibition were posted on Twitter accounts. An

21 James B. Gardner, “Contested Terrain: History, Museums, and the Public,” The Public Historian 26, no. 4 (2004): 11. 
unintended consequence was that people used these self-made photographs to offer comments about their school memories evoked by their visit to the exhibit.

Tensions with the event organizer: Finally, we would like to discuss the potential tensions among event organizers. In this exhibition, as mentioned earlier, an academic historian and an educational interest group - the Ángel Llorca Foundation acted together as event organizers. Given the various mutual interests, this was a potential source of tensions. To illustrate these tensions, we will go into more detail about the selection of photos for the exhibition, in particular the choice for the exhibition poster. As a methodological source, we use the email and WhatsApp discussions held between those involved in the event organization.

\section{From Tension to Consensus: The Selection of the Exhibition Poster}

In this section, we will show how the interplay between the groups involved with the organization of Madrid, ciudad educadora 1898-1938. Memoria de la escuela pública operated in relation to the selection of visual images. We will focus on the choice for the poster of the exhibition as a way of explaining why some images ended up being displayed to the public while others did not. Let us begin with the first selection of seven images that were being considered for use. The starting point was the image archive of 500 photographs mentioned above, collated by the first author over twenty years, and enriched for the exhibition. It was placed on the Google Drive of the Ángel Llorca Foundation and shared by the historian of education with the foundation's members, including the exhibition organizers and designers. All these people were specifically asked to browse through the database, add new material if necessary, and select an appropriate image that could serve as a poster for the exhibition. This was no easy task, considering that the poster was to be shown all over the city of Madrid, on display screens placed by the City Council in the main streets and squares.

The discussion and selection of the photograph that would be chosen to represent the message of the exhibition took place on WhatsApp. Seven images were shared within the discussion group of the Ângel Llorca Foundation. In prior conversations, the Foundation's teachers had expressed two wishes: that the images shown in the exhibit be inclusive - that is, that they show boys and girls together - and that the central theme of the expositional discourse be childhood play. Such wishes posed a challenge to the historian in charge; coeducation was rare during the period and most schools were single sex. As for the images captured in photographs, these tended to be classroom settings rather than playgrounds or recess situations. As a result, the seven images in Fig. 5.1 were chosen from among all of the images available in the 


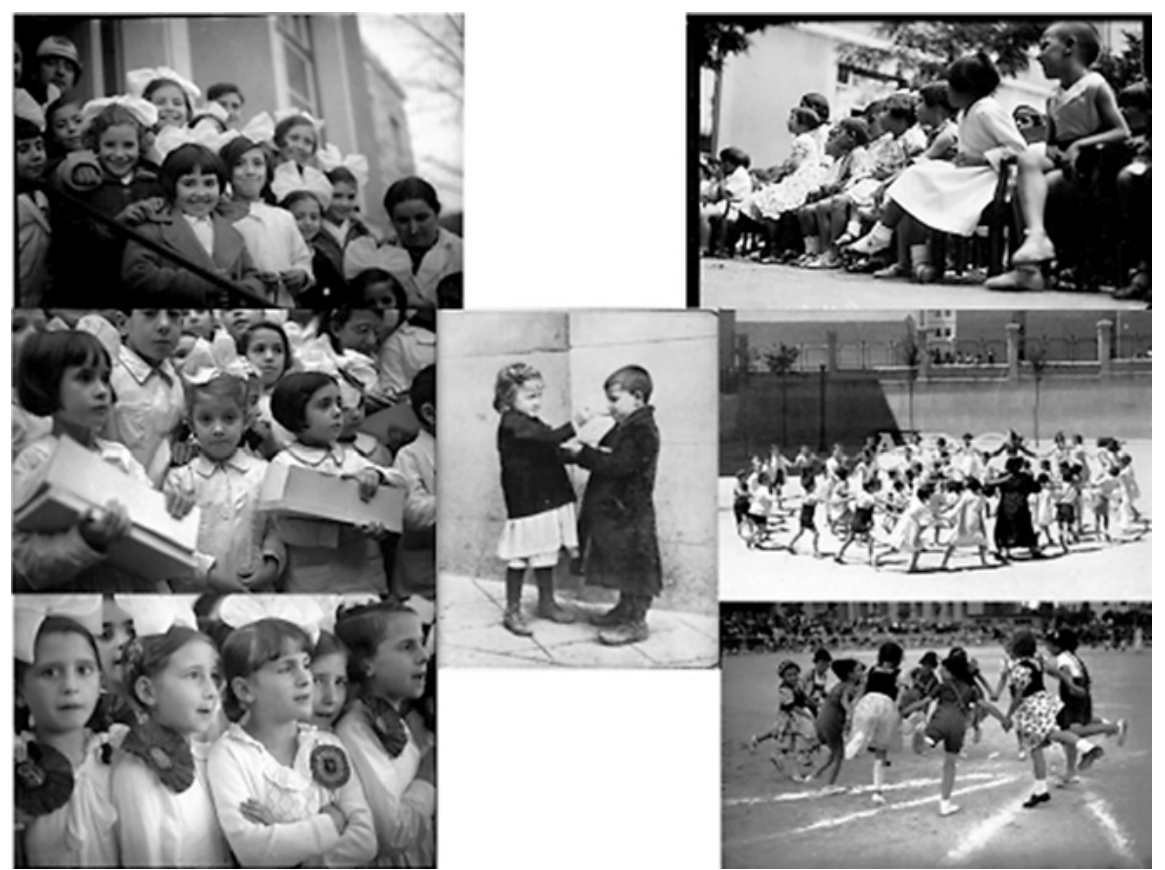

Fig. 5.1: The seven possible poster images selected for the exhibition Madrid, ciudad educadora 1898-1938. Memoria de la escuela pública.

Google Drive of the Foundation. ${ }^{22}$ Six of them are from the period of the Second Republic (1931-1938), and one is from the preceding monarchy (1911).

The initial selection of seven photos, which all appear to have been taken outdoors, show larger groups of children, except for one image showing only a boy and a girl. Furthermore, the impression is that most of these look like snapshots rather

22 Fig. 5.1 is a composition made from the seven preselected photographs for possible use as the iconic image of the exhibition that would appear on the poster. The three photos on the left (from top to bottom) show the inauguration of a public school (April 1936), handing out shoes to boys and girls in a municipal school (1936), and a group of girls singing (June 1935). The three photographs on the right (from top to bottom) show a party in honor of students graduating from this stage of school (July 1935), boys and girls playing in a school playground (August 1936), and another group of children, without teachers, playing together (June 1936). The image in the center shows a girl feeding a boy in a schoolyard (1911). Five of these photographs are from the photographic study "Alfonso", produced by photographers Alfonso Sánchez García and Alfonso Sánchez Portela, whose enormous collection is housed at the Archivo General de la Administración; the sixth picture was taken by photographers Albero and Segovia, and is from the photographic archive of the $A B C$ newspaper; the middle photograph was used on the cover of the illustrated journal Nuevo Mundo from December 7, 1911. 
than photos deliberately composed by the photographer, again, with the exception of the boy and girl. Said photograph was well received by several members of the Ángel Llorca Foundation who, in addition to admiring its vitality, found it to be "emblematic" in its portrayal of the positive relationship between the two children. From an historical point of view, the image is quite unusual for its time - 1911 given the strict separation of sexes that was then prevalent in public schools.

The last photograph is the odd one out although, in a way, this could also apply to two photographs that show objects that attract attention: the image with two boxes, and the image with (apparently) multi-colored cockades. Both photographs are intriguing because of the questions they raise: What is in the boxes? Why doesn't the girl looking directly at the camera have a box? What do those cockades mean? After an initial round of discussion, the latter two photographs were discarded for the exhibition poster; in both instances, they were deemed too complex as an initial introduction to the exhibition. The subject of the photograph with the boxes (handing out shoes to poorer children in public schools) was not considered ideal, nor was the fact that the group of singers does not include any boys.

Curiously, although the exhibition was about public schools, there are no school buildings visible in the photos selected for the poster. We see parts of buildings and walls, but children are the dominant actors in the pictures. There is a logic to this, given that the members of the event organizer are part of a progressive education movement that prefers child-centered pedagogy over teacher-centered approaches. The only glimpse of a school can be seen in the background of the photo of the Instituto-Escuela, a middle-class secondary school in Madrid (Fig. 5.1, lower right) that had several mixed-sex primary school classes starting in 1918. While the Foundation's teachers liked the subject matter of the image, they ultimately decided against using a photograph depicting the only public school in Madrid conceived for middle class children as an image for the exhibition.

After a few rounds of discussion, the final choice came down to two photographs: the girl feeding the boy (1911), (Fig. 5.1, center), and the picture of a schoolyard with a mixed group of children playing/dancing together with their teachers (1936) (Fig. 5.1, center right). We will structure the discussion about these two images supported by the concepts of denotation and connotation. ${ }^{23}$ This is a readily accepted way of analyzing visual images, ${ }^{24}$ which we shall use to summarize the discussion about these two images in two tables. These tables show that starting with denotation (what do we see?), there are several possible connotations (what does it mean?) that differed for the parties involved in the selection process.

23 Susan Sontag, ed., A Barthes Reader (New York: Hill and Wang, 1982).

24 Gillian Rose, Visual Methodologies. An Introduction to Researching with Visual Materials (London: Sage, 4th edition, 2016). 
Tab. 5.2: Visual analysis of Fig. 5.1 (center), shown at the Exhibition Madrid, ciudad educadora 1898/1938. Memoria de la escuela pública.

\begin{tabular}{lll}
\hline Denotation & Connotation & \\
\hline Plate and spoon & History of education & Educational interest \\
\hline Girl and boy & Help & Charity \\
\hline Old shoes/ oversized coat & Lower class & Poverty \\
\hline
\end{tabular}

Table 5.2 shows the conflicting interpretation of the same image by two different parties. From the perspective of a historian, the photograph of the girl feeding the boy indicates an educational situation that was exceptional for the time. In general, boys and girls went to separate schools, therefore seeing them together in one image points to the practice of coeducation, which at the time scarcely existed in public schools. Another historical observation has to do with the impoverished way in which both children are dressed. Old shoes and oversized coats indicate a lowerclass background, precisely the socioeconomic group that was present in large numbers in the public education sector. We can see, then, how in a historical sense the picture of the girl feeding the boy symbolizes public schools from the past, while it also stresses the idea of helping fellow human beings.

Nevertheless, from a present-day perspective, we note something different. Helping one another can be interpreted as an act of charity. Certain social groups depend on more powerful groups to feed them in times of trouble. One child feeding another also depicts a situation of inequality, while an interpretation made in terms of social or economic status could easily be changed by focusing on the poverty conveyed in the image. In short, are defenders of public education going to want to present an exhibition about public schools with a poster depicting poverty and inequality? The answer in this case was clearly negative, this no being expressed implicitly in phrases shared by various members of the Ángel Llorca Foundation in the WhatsApp discussion they held on September 9, 2018: "I think the photo of the children feeding each other is lovely. But at the same time there is something intrinsic to the image and to the message it projects. . . I don't believe this is the idea we want to convey. . ." This observation was seconded immediately by another member: "I agree with Ana...it could be misconstrued." This brings us to the arguments in favor of and against the remaining image: a mixed group of children performing a circle dance with adults.

Table 5.3 shows the connotations that evolved from the discussion of the three groups involved in selecting the exhibition poster: the historian of education, the educational interest group, and the creative designers. Again, we see how the same elements can be interpreted in different ways by different parties - at least at first glance. After a discussion - or in the words of Guba and Lincoln, as a result of a hermeneutic/ 
dialectical process - a joint construction will emerge that is (hopefully) shared by all participants. ${ }^{25}$ Stakeholders may also reach some degree of consensus beforehand.

Tab. 5.3: Visual analysis of Fig. 5.1 (center right) shown at the exhibition Madrid, ciudad educadora 1898/1938. Memoria de la escuela pública.

\begin{tabular}{|c|c|c|c|}
\hline \multirow[t]{2}{*}{ Denotation } & \multicolumn{3}{|l|}{ Connotation } \\
\hline & History & Educational interest & Creative design \\
\hline Circle dance (Corro) & Cooperation & Game & Movement \\
\hline Boys and girls & Coeducation & Inclusion/ Diversity & Gender \\
\hline Young and old people & Pupils and teachers & Equality & Age groups \\
\hline Black dress/ white dots & Female teacher & Teacher centeredness & Contrast/ Pattern \\
\hline Open space & Schoolyard & Free play & Canvas \\
\hline Wall & School & School & School \\
\hline
\end{tabular}

Once the organizers had reached a consensus about the photo that was to be the emblem for the exhibition, the Ángel Llorca Foundation met with the creative designers, who were thrilled with the choice of an image which, as they explained, could be recognized immediately and without any explanation as depicting a school. A discussion ensued with the historian of education, who brought up some of the arguments and discoveries expounded upon in a workshop organized by Ian Grosvenor and Martin Lawn during the International Standing Conference for the History of Education (ISCHE) in Berlin (August 2018). How could all the participants be so certain that the photograph showed a school? What was it that identified or symbolized a school in this picture? The high point of the discussion came with the realization especially on the part of the progressive teachers from the foundation - that the key was the exterior wall surrounding the playground. This is what made is so easily recognizable; virtually all school buildings and school grounds in Spain are surrounded by high walls that isolate and separate them from the outside world. An attempt at editing was made and the designers eliminated the wall from the image with Adobe Photoshop. The result, however, was to no one's liking; it seemed as if the children were playing in some sort of meadow, while the notion of a school had disappeared entirely. Finally, a new meaning for the image was constructed among everyone: Instead of supervision, the wall represented protection and safety for the students, especially from the dangers of the war that had broken out on July 18, 1936, scarcely a month before the photograph was taken.

25 Egon G. Guba \& Yvonna S. Lincoln, Fourth Evaluation Research (Newsbury Park: Sage, 1989). 
The fact that we again see boys and girls together in the picture points to a historical feature of progressive public schools: coeducation. In the educational terms of the present era, we are inclined to see inclusion and diversity. But what is most remarkable is the fact that the Ângel Llorca Foundation opted for the only photograph of the seven in which children and teachers are shown together. This collective of teachers, which always identified strongly with the educational legacy passed on by the Spanish Progressive Education movement of the early twentieth century, chose an image in which the figure of the teacher occupies a central position. This would seem to go against the universally understood iconographical feature of Progressive Education where, if teachers are shown at all, they are invariably in a marginal, secondary position in relation to the children. ${ }^{26}$ Nor does the scene portray the teacher in her usual classroom setting, going about the business of instructing her students. In this sense, the image defies pedagogical conventions, taking the teacher out of her normal space of control and placing her in a situation where she is on an equal plane with the children as she plays with them. The teacher figure in this picture was in fact the subject of considerable debate, which focused on two possible ways of "editing" her: one proposal was to simply edit her out of the picture (there is a draft version of the poster showing exactly this); the other was to lighten her dress, making it less black; the intense color of the dress, which makes her the center of attention too much, could be resolved graphically. Finally, the contrast in the photograph was lowered, which served to make the dots on the dress more pronounced. By applying a dotted structure to the background, a more direct relationship was established between foreground and background. With these small tweaks, the definitive photograph that was to be used for the exhibition poster, the leaflet, the catalogue, and the program of conferences and activities was approved and published. (Figs. 5.2, 5.3, 5.4 and 5.5).

However, in the publication put together by the educational interest group, the Ángel Llorca Foundation, the wall has disappeared entirely. Said publication was a catalogue designed to help children better understand the exhibition. The curious picture shown on the cover (Fig. 5.6) was drawn by the illustrator Clara Luna. This artist has always had an interest in "accessible drawing" and in using a kind of graphic language in which stories or ideas may be easily understood by young children, or those who may not be able to read. In this case, the cover uses the same central concept of the circle dance, but instead of the school being represented by a surrounding wall, it is symbolized by the use of letters that fall from the sky like

\footnotetext{
26 Catherine Burke and Ian Grosvenor, "The Progressive Image in the History of Education: Stories of Two Schools," Visual Studies 22, no. 2 (2007): 159-163; Sjaak Braster and María del Mar del Pozo Andrés, "Picturing the Progressive Education: Images and Propaganda in The New Era (19201939)," Historia y Memoria de la Educación 8 (2018): 177-79; Sjaak Braster and María del Mar del Pozo Andrés, "From Savages to Capitalists: Progressive Images of Education in the UK and the USA (1920-1939)," History of Education 49, no. 4 (2020): 581.
} 


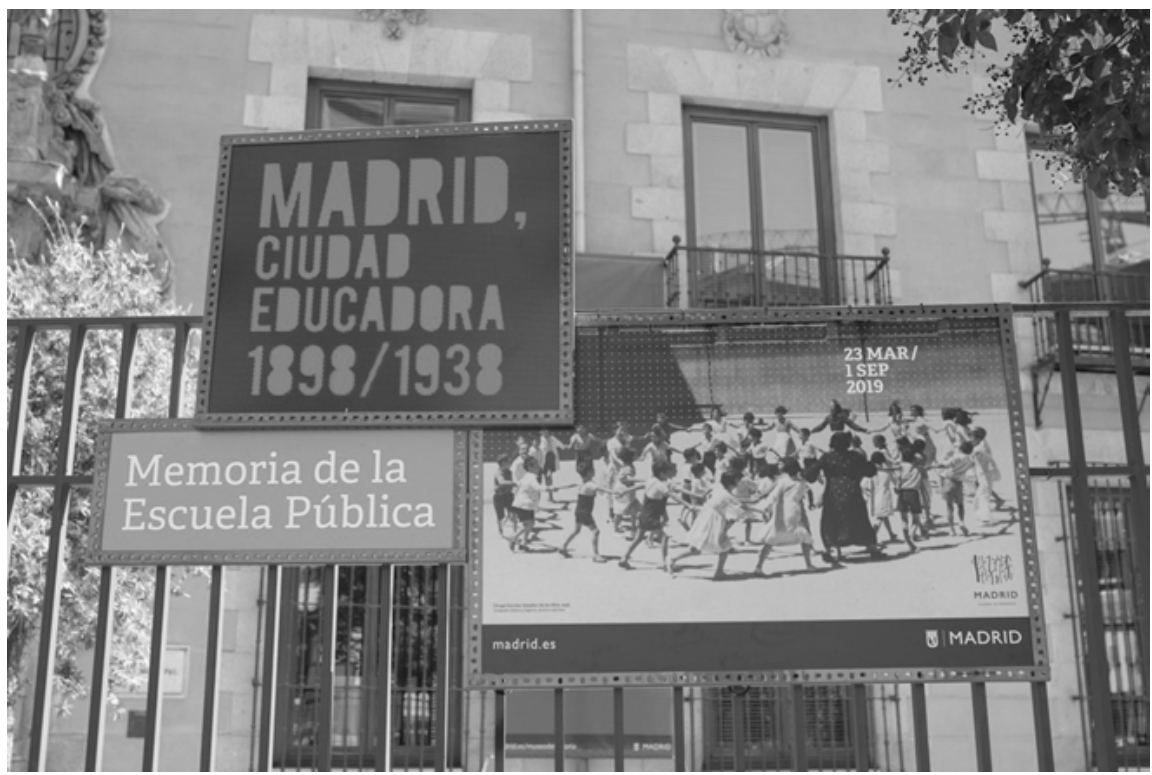

Fig. 5.2: Exhibition poster at the entrance to the Madrid Museum of History.

magical rain. There are other differences from the original image: the teacher is situated in a less dominant role - at one end of the ring instead of in the middle -, she is wearing a lighter colored dress, and appears to be younger. She is clearly very happy.

Initially, the Ângel Llorca Foundation (the educational interest group for this exhibition) had in mind a poster in which children would be the main (possibly even the only) actors, and where their freedom, creativity, and playfulness would be a main theme. For them, the circle dance (corro) was nothing more than that: a dance or a game that could be performed outside the school building without any restrictions. The corro dance does in fact have a long tradition in Spanish children's games. Typically, it was practiced by girls and women, constituting a feminine space not only for acculturation and socialization, but also for free expression, protest, diversion, and equality. ${ }^{27}$ Photographs of corros in school playgrounds in Spain are virtually non-existent before the 1930s, at which point we begin to find an abundance of depictions of boys and girls dancing together - a delightful symbol of inclusiveness. We have numerous photographs from the Civil War years of boys and girls in corros at the camps organized by the government in order to move students as far as possible

27 Mari Cruz Garrido Pascual, El corro de las niñas, el círculo de las mujeres. Un repaso al juego del corro desde sus orígenes como elemento de la cultura femenina (Madrid: Horas y Horas, 2010), 158166. 


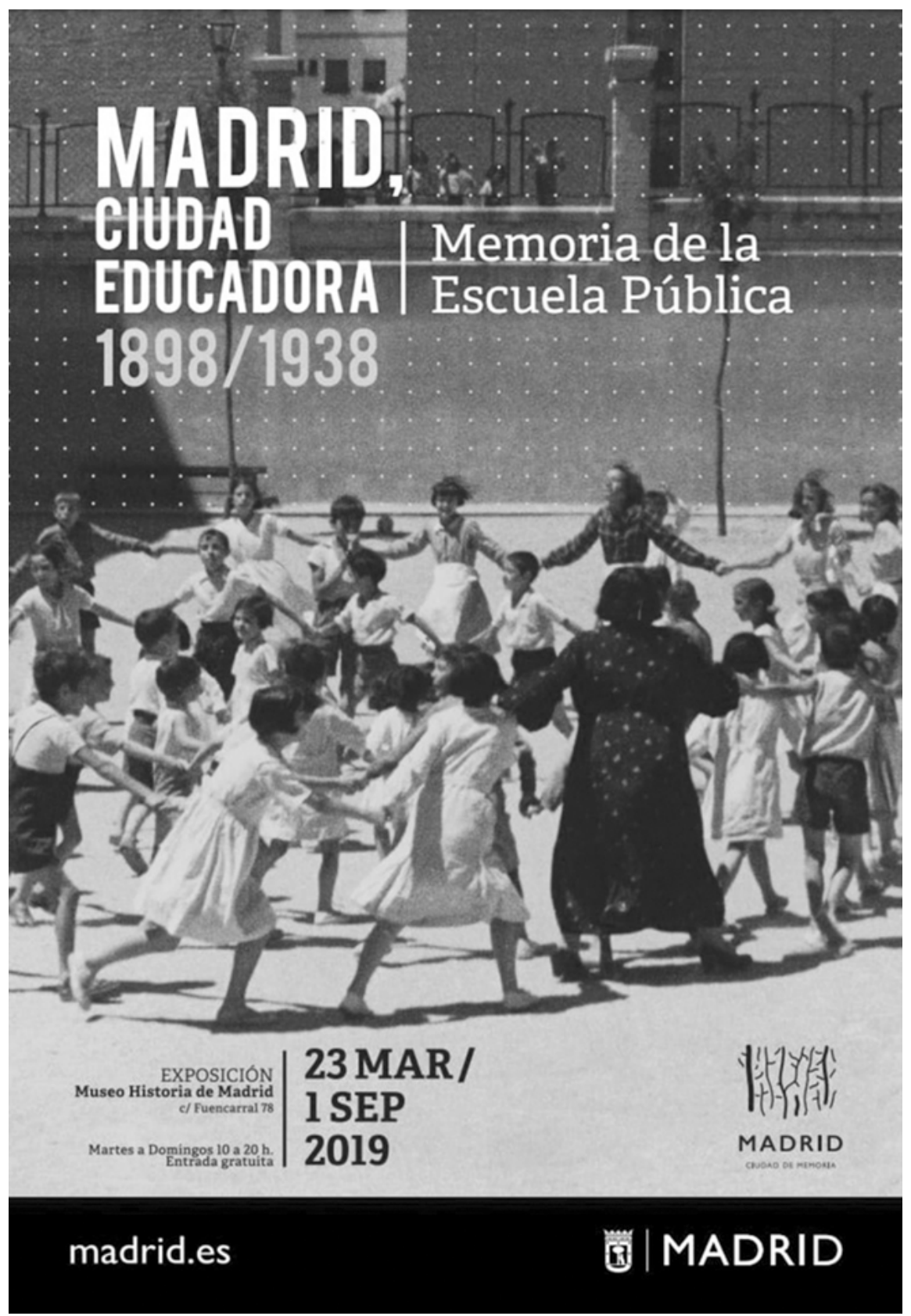

Fig. 5.3: Cover of the exhibition leaflet. 


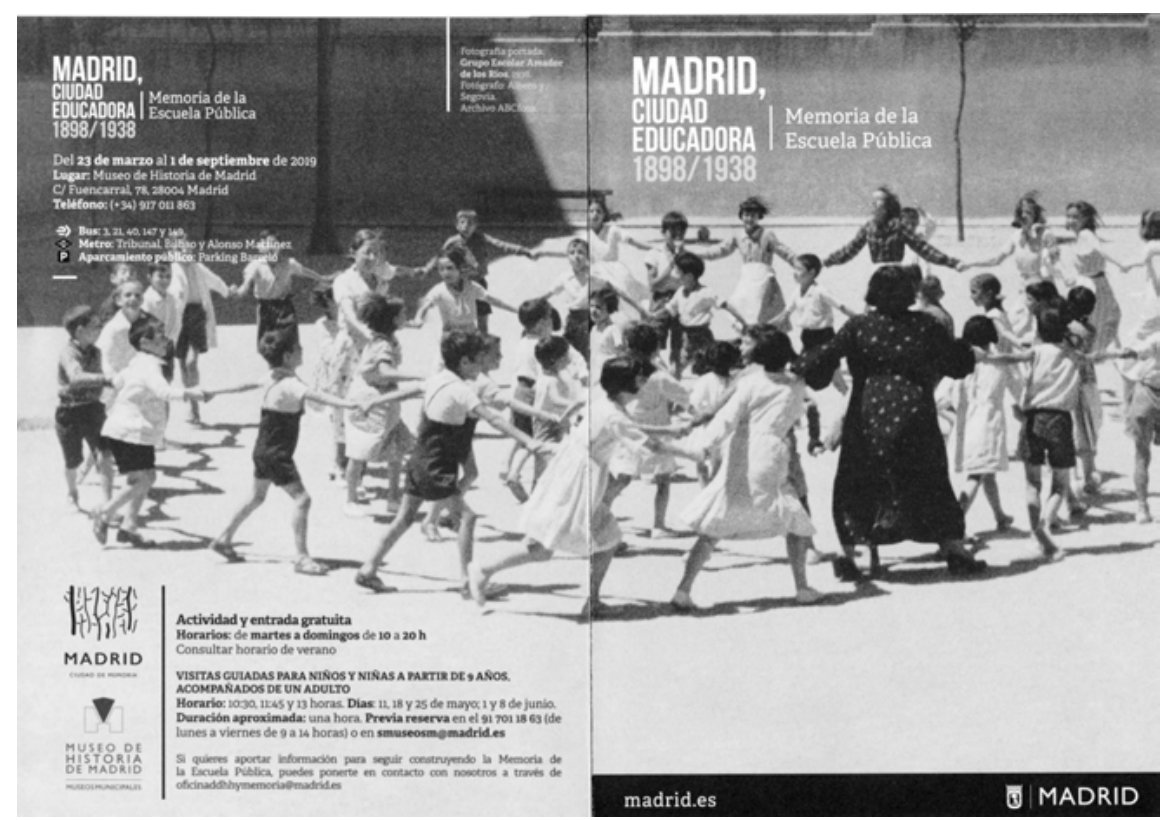

Fig. 5.4: Cover of the exhibition catalog.
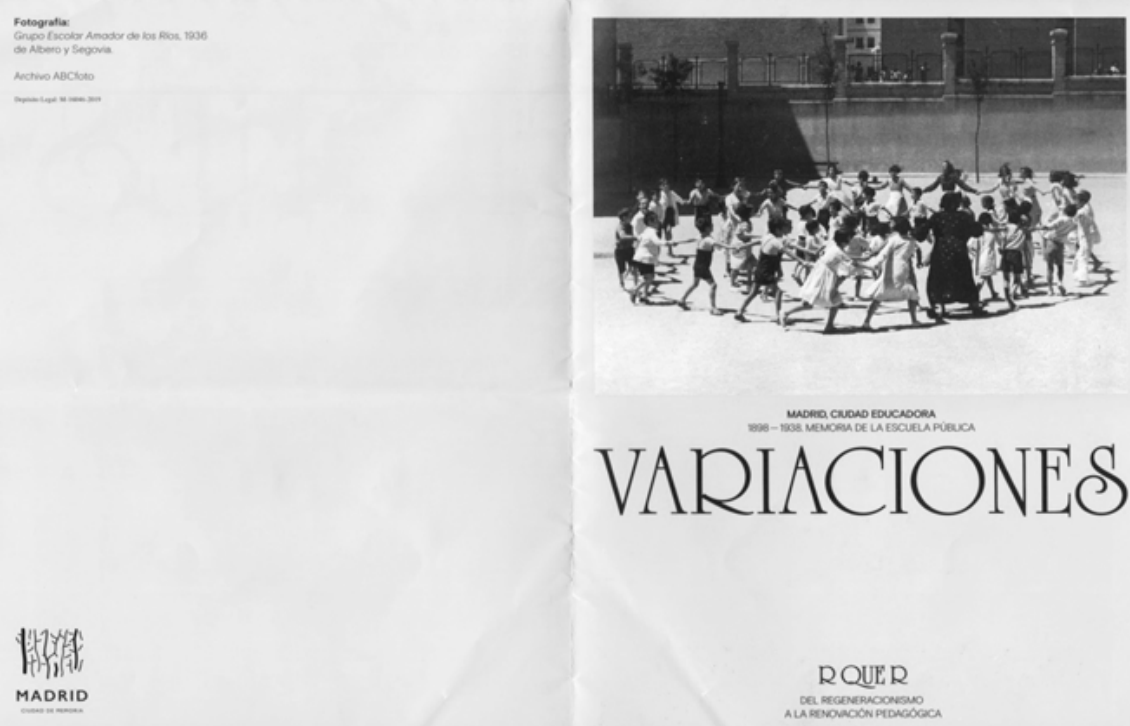

Fig. 5.5: Program of conferences organized in conjunction with the exhibition. 


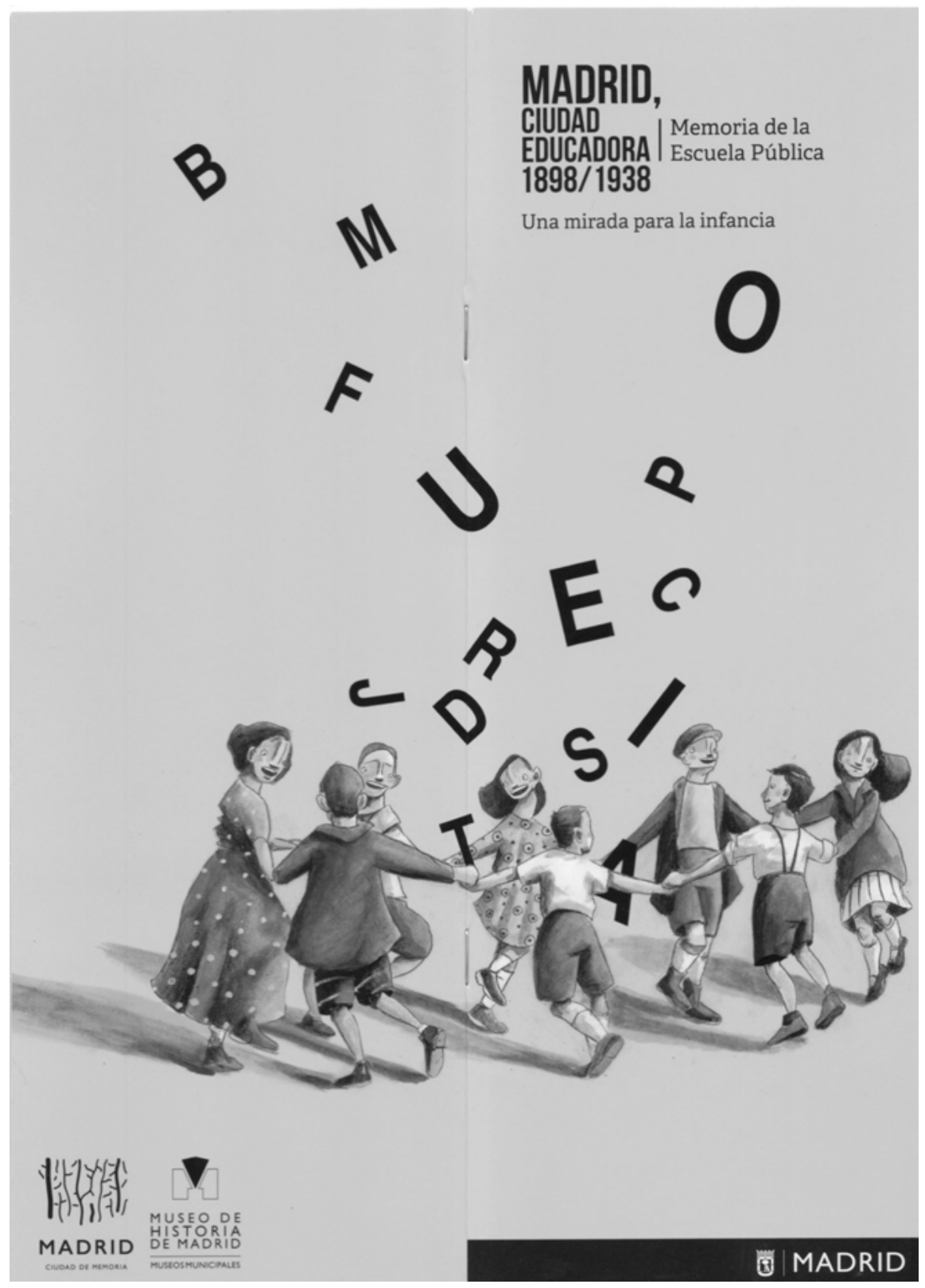

Fig. 5.6: Exhibition catalogue designed for children. Illustrator: Clara Luna. 
from battlegrounds. In fact, so numerous are these images - taken at a crucial point in the war - that we can only conclude that they were seen as representing ideals of peace, union, and the school community. ${ }^{28}$

This new interpretation, supported by prior historical research, was accepted by all the stakeholders, who assumed this image of the corro as an expression of cooperation - a central element of the historical identity of Madrid's public schools. The fact that the circle is formed by boys and girls (pupils and teachers) also refers to the accessibility of public education to all socioeconomic, ethnic, and racial groups, both then and now. In a way, the image stands for equality between various sociocultural groups, while the happiness of children dancing in the open air underlines the idea of educational freedom. Overall, the image triggers a variety of emotions that in general positively relate to the identity of public schools.

\section{Conclusion and Discussion: The Exhibition in Times of Coronavirus}

In this article, we have provided examples of the tensions that can arise when an academic historian engages in public history by organizing a historical exhibition. In this case, the tensions were resolved relatively easily. The interpersonal relationships between the people who comprised the group of event organizers were positive, the event owners had enough faith in the group to grant them autonomy, and there was no question about the historical expertise of the academic historian. In the end, each party got what it wanted. The exhibition also fulfilled a need shared by all parties: to provide knowledge to a wide audience about the (hitherto unknown) qualities of Madrid's public schools in the past. The exhibition served to help the people of Madrid find their own identity through the path of collective memory, and to confront mixed feelings of pride and melancholy regarding the educational inventiveness of their city. A well-known writer from Madrid, Almudena Grandes, highlighted this evocative aspect of the exhibition in her weekly column for the national newspaper El País, where she wrote that she had no choice but to share her feelings about the exhibition because the Madrilenians "we love ourselves so little that we really need an injection of self-esteem like this."29 We will have to study more cases to understand how historians operate when embarking on the path of public history. Our conclusion, provisional as it may be, is that among the

28 Sjaak Braster and María del Mar del Pozo Andrés, "Education and the Children's Colonies in the Spanish Civil War (1936-1939): The, Images of the Community Ideal,” Paedagogica Historica 51, no. 4 (2015): 471-472.

29 Almudena Grandes, “Una inyección de autoestima,” El País, April 14, 2019. 
indispensable conditions for a successful journey are shared objectives, indisputable expertise, and mutual trust.

We finished writing this paper just a year after the closure of the exhibition $M a$ drid, ciudad educadora 1898/1938. Memoria de la escuela pública. The exhibition displayed some 500 photographs. The number of images dealing with hygiene issues (hand washing, baths and showers, school doctors, the use of outdoor spaces) is surprising, and can be at least partially attributed to the influence of the hygienist movement and Progressive Education trends in schooling circles. Although the historian was perfectly aware of the devastating epidemic that took siege of Madrid in 1918 - the "Spanish Flu" - and led to the city's schools being closed for several weeks in October of that year, she did not see any relationship between this event and the ensuing changes, which are clearly visible in the school architecture as well as in students' hygienic practices.

And yet, our current pandemic has transformed the recollection of the exhibition for those who saw it. What seems to stick most with visitors has to do with the open spaces contained within these historical schools. Such spaces, which the exhibition organizers associated with playtime and free activities, can be seen now as alternatives, as settings where open-air instruction could be given within the school. Most school buildings from before 1939 have spacious rooftops and patios, and some of the parents' associations of Madrid public schools launched an initiative in March of 2020 for the recovery of these spaces for educational uses. ${ }^{30}$ For this purpose, they requested from the organizers the photo archive put together for the exhibition; this would be their way of underscoring the pedagogical tradition on which their project was grounded. The story is not without irony: a collection of photographs chosen to portray the joy and carefree play of young children is being used, scarcely one year later, to justify the conversion of all the school's play spaces into one enormous classroom.

\section{Image Credits Fig. 5.1}

A girl feeding a boy in the courtyard of the Vallehermoso school, Nuevo Mundo, December 7, 1911, n.p. Photographer: Walter Studio (Francisco Toda).

Donation of shoes granted by Madrid City Council the children in public schools (January 1936). Alfonso Archive. Archivo General de la Administración (AGA), 005750. Photographer: Alfonso Studio (Alfonso Sánchez García and Alfonso Sánchez Portela).

Festival celebrated by the students of the Instituto-Escuela commemorating the end of the academic year (June 1936). Alfonso Archive. AGA, 003865. Photographer: Alfonso Studio (Alfonso Sánchez García and Alfonso Sánchez Portela).

30 "Proyecto - Azoteas Escolares," https://azoteasescolares.wordpress.com/ (accessed September 25, 2020). 
Festival celebrated by the students of the Pablo Iglesias school commemorating the end of the academic year (July 14, 1935). Alfonso Archive. AGA, 025292. Photographer: Alfonso Studio (Alfonso Sánchez García and Alfonso Sánchez Portela).

Group of boys and girls during the visit of the President of the Second Republic to their school (April 1936). Alfonso Archive. AGA, 005344. Photographer: Alfonso Studio (Alfonso Sánchez García and Alfonso Sánchez Portela).

Group of singing girls during the inauguration of the Lope de Vega school by the President of the Second Republic (June 1935). Alfonso Archive. AGA, 005664. Photographer: Alfonso Studio (Alfonso Sánchez García and Alfonso Sánchez Portela).

Amador de los Ríos School, children playing in the courtyard together with schoolteachers (August 1936). Photographical Archive $A B C$. Photographers: Albero and Segovia (Félix Albero Trullen and Francisco Segovia García).

\section{Bibliography}

"Acción Educativa." Accessed August 5, 2020. http://accioneducativa-mrp.org/.

Bachar, Jerad. "Measuring the Impact of Exhibitions." Exhibition World 4, no. 4 (2015). Accessed August 3, 2020. https://www.exhibitionworld.co.uk/2015/07/02/measuring-the-impact-ofexhibitions.

Braster, Sjaak and María del Mar del Pozo Andrés. "Education and the Children`s Colonies in the Spanish Civil War (1936-1939): The Images of the Community Ideal.” Paedagogica Historica 51, no. 4 (2015): 455-477.

Braster, Sjaak, and María del Mar del Pozo Andrés. "From Savages to Capitalists: Progressive Images of Education in the UK and the USA (1920-1939)." History of Education 49, no. 4 (2020): 571-595.

Braster, Sjaak, and María del Mar del Pozo Andrés. "Picturing the Progressive Education: Images and Propaganda in The New Era (1920-1939)." Historia y Memoria de la Educación 8 (2018): 147-193.

Burawoy, Michael. "For Public Sociology." American Sociological Review 70, no. 1 (2005): 4-28.

Burke, Catherine, and Ian Grosvenor. "The Progressive Image in the History of Education: Stories of Two Schools." Visual Studies 22, no. 2 (2007): 155-168.

Cauvin, Thomas. Public History: A Textbook of Practice. London: Routledge, 2016.

Commission of the European Communities and International Association of Professional Congress Organizers. Meeting Industry Terminology. Luxembourg: Office for Official Publications of the European Communities, 1992 (accessed August 2, 2020). https://termcoord.eu/wp-content/ uploads/2016/07/meeting-industry-terminology1.pdf.

Dean, David, ed. A Companion to Public History. Hoboken, NJ: Wiley, 2018.

Dowling, Stephen. "Coronavirus: What Can We Learn From the Spanish Flu." March 3, 2020. https://www.bbc.com/future/article/20200302-coronavirus-what-can-we-learn-from-the-span ish-flu (accessed July 25, 2020).

“Fundación Ángel Llorca." http://www.fundacionangelllorca.org/fundacion/ (accessed August 5, 2020).

Fundación Ángel Llorca. Madrid, ciudad educadora 1898/1938. Una mirada para la infancia. Madrid: Ayuntamiento de Madrid, 2019.

Gardner, James B. “Contested Terrain: History, Museums, and the Public." The Public Historian 26, no. 4 (2004): 11-21. 
Gardner, James B., and Paula Hamilton, eds. The Oxford Handbook of Public History. Oxford: Oxford University Press, 2017.

Garrido Pascual, Mari Cruz. El corro de las niñas, el círculo de las mujeres. Un repaso al juego del corro desde sus orígenes como elemento de la cultura femenina. Madrid: Horas y Horas, 2010.

Grandes, Almudena. “Una inyección de autoestima.” El País, April 14, 2019.

Guba, Egon G., and Yvonna S. Lincoln. Fourth Evaluation Research. Newsbury Park: Sage, 1989.

International Congress and Convention Association. "The definition of MICE." https://www.icca world.org/aeps/aeitem.cfm?aeid=29 (accessed August 2, 2020).

Interview with Txema Urquijo. elDiario.es, February 21, 2020. https://www.eldiario.es/madrid/ex responsable-memoria-historica-carmena-comisionado_1_1121225.html (accessed September 2, 2020).

Lauder, Hugh, Phillip Brown, Jo-Anne Dillabough and A.H. Halsey. Education, Globalization and Social Change. New York: Oxford University Press, 2006.

Lyon, Cherstin M., Elizabeth M. Nix, and Rebecca K. Shrum, eds. Introduction to Public History: Interpreting the Past, Engaging Audiences. Lanham, Boulder, New York, London: Rowman \& Littlefield, 2017.

Morgan, Kenneth. Edward Colston and Bristol. Local History Pamphlets series, no. 96. Bristol: The Bristol Branch of the Historical Association, 1999. http://www.bris.ac.uk/Depts/History/bris tolrecordsociety/publications/bha096.pdf (accessed August 1, 2020).

Museo de Historia de Madrid. "Madrid, ciudad educadora 1898/1938 - Memoria de la escuela pública." https://www.esmadrid.com/agenda/madrid-ciudad-educadora-18981938-memoriaescuela-publica-museo-historia\# (accessed August 28, 2020).

Pozo Andrés, María del Mar, del. Currículum e identidad nacional. Regeneracionismos, nacionalismos y escuela pública (1890-1939). Madrid: Biblioteca Nueva, 2000.

Pozo Andrés, María del Mar, del. "Madrid, a showcase for national pedagogical renovation (1898/ 1936)." In Madrid, ciudad educadora 1898/1938. Memoria de la escuela pública, edited by María del Mar del Pozo Andrés, 297-325. Madrid: Ayuntamiento de Madrid, 2019.

Pozo Andrés, María del Mar, del, ed. Madrid, ciudad educadora 1898/1938. Memoria de la escuela pública. Madrid: Ayuntamiento de Madrid, 2019.

Pozo Andrés, María del Mar, del. "Las escuelas públicas históricas de Madrid.” In Madrid, ciudad educadora 1898/1938. Memoria de la escuela pública, edited by María del Mar del Pozo Andrés, 379-84. Madrid: Ayuntamiento de Madrid, 2019.

Pozo Andrés, María del Mar, del. Urbanismo y Educación. Política educativa y expansión escolar en Madrid (1900-1931). Madrid: Universidad de Alcalá, 1999.

"Proyecto - Azoteas Escolares." https://azoteasescolares.wordpress.com/ (accessed September $25,2020)$.

Rose, Gillian. Visual Methodologies. An Introduction to Researching with Visual Materials. London: Sage, 4- edition, 2016.

Sayer, Faye. Public History: A Practical Guide. London: Bloomsbury, 2019.

Sontag, Susan, ed. A Barthes Reader. New York: Hill and Wang, 1982.

Tennessen, Herman. “History is science.” The Monist 53, no. 1 (1969): 116-33, DOI: https://doi.org/ $10.5840 /$ monist19695312.

Toye, Richard. "Yes, Churchill Was a Racist. It's Time to Break Free of his 'Great White Men' View of History." July 10, 2020. https://edition.cnn.com/2020/06/10/opinions/churchill-racist-greatwhite-men-view-toye-opinion/index.html (accessed August 1, 2020). 
